\begin{tabular}{lcc}
\hline Volume 21 & Nomor 2, Juli 2020 & Halaman 114-126 \\
URL: https://jurnal.unej.ac.id/index.php/SEMIOTIKA/index & E-ISSN: 2599-3429 & P-ISSN: 1411-5948 \\
\hline
\end{tabular}

\title{
TINDAK TUTUR ILOKUSI DALAM INTERAKSI JUAL BELI DI PASAR TEMPUREJO, JEMBER
}

\author{
ILLOCUSION SPEECH ACTS IN BUYING AND SELLING \\ AT TEMPUREJO MARKET, JEMBER
}

\author{
Resti Purnama Sari ${ }^{1}$, Akhmad Sofyan ${ }^{2}$, A. Erna Rochiyati S. ${ }^{3 *}$ \\ ${ }^{1}$ Alumni Fakultas Ilmu Budaya Universitas Jember \\ ${ }^{2,3}$ Fakultas Ilmu Budaya Universitas Jember \\ *Corresponding Author: erna.rochiyati@gmail.com \\ Informasi Artikel: \\ Dikirim: 31/1/2020; Direvisi: 12/4/2020; Diterima: 23/6/2020
}

\begin{abstract}
Tempurejo Market is a traditional market mostly visited by people who live in Tempurejo Village and its surroundings to varying the speech acts used. Sellers and buyers have an interesting narrative method or strategy so that they achieved a deal. The speech acts that are often used in buying and selling interactions at Tempurejo Market are illocutionary speech acts and bargaining strategies so that the research problem is how illocutionary speech acts and bargaining strategies are used between sellers and buyers in Tempurejo Market, Jember Regency. This study describes illocutionary speech acts and bargaining strategies in buying and selling interactions at this market. The method used in this research is descriptive and equivalent. The second method is used to match the data with illocutionary speech act theory. The results showed five kinds of illocutionary speech acts: assertive, directives, expressive, commissives, and declarative. Illocutionary speech acts often used in buying and selling interactions at Tempurejo Market are assertive speech and expressive speech. The bargaining strategies used in the buying and selling interactions at Tempurejo Market offer strategy, bargaining strategy, the bid approval strategy, and the seller strategy to reject the offering. The bargaining strategy often used in buying and selling interactions at Tempurejo Market is the offering strategy.
\end{abstract}

Keywords: buying selling, illocution, market, speech acts

Abstrak

Pasar Tempurejomerupakan pasar tradisional yang sering dikunjungi oleh masyarakat yang tinggal di Desa Tempurejo dan sekitarnya sehingga tindak tutur yang digunakan beragam. Penjual dan pembeli memiliki cara atau strategi bertutur yang menarik agar tuturan yang disampaikan tercapai sesuai target. Tindak tutur yang sering digunakan yaitu tindak tutur ilokusi dan strategi tawar menawar sehingga rumusan masalah dalam penelitian ini bagaimana tindak tutur ilokusi dan strategi tawar-menawar yang digunakan antara penjual dan pembeli di Pasar Tempurejo Kabupaten Jember. Penelitian ini bertujuan untuk mendeskripsikan tindak tutur ilokusi dan strategi tawar-menawar dalam interaksi jual beli di Pasar Tempurejo Kabupaten Jember. Metode yang digunakan adalah metode deskriptif dan metode padan. Metode padan digunakan untuk memadankan data dengan teori tindak tutur ilokusi. Hasil penelitian bahwa terdapat lima macam tindak tutur ilokusi, yaitu: asertif, direktif, ekspresif, komisif, dan deklaratif. Tindak tutur ilokusi yang sering digunakan dalam interaksi jual beli di Pasar Tempurejo yaitu tuturan asertif dan tuturan ekspresif. Strategi tawar-menawar yang digunakan dalam interkasi jual beli di 
Tindak Tutur Ilokusi dalam Interaksi Jual Beli di Pasar Tempurejo, Jember (Resti Purnama Sari, Akhmad Sofyan, A. Erna Rochiyati S.)

Pasar Tempurejo yaitu: strategi menawarkan, strategi menawar, strategi menyetujui tawaran dan strategi penjual menolak tawaran. Strategi tawar-menawar yang sering digunakan dalam interaksi jual beli di Pasar Tempurejo yaitu strategi menawarkan.

Kata kunci: jual beli, ilokusi, pasar, tindak tutur

\section{PENDAHULUAN}

Bahasa adalah sistem lambang bunyi yang arbitrer yang dipergunakan oleh masyarakat untuk bekerja sama, berinteraksi, dan mengidentifikasikan diri (Kridalaksana, 1993:21). Bahasa adalah alat komunikasi antara anggota masyarakat berupa simbol bunyi yang dihasilkan oleh alat ucap manusia (Keraf, 2001:1). Melalui bahasa, manusia dapat bekerja sama dan berkomunikasi. Komunikasi adalah serangkaian tindak komunikatif atau tindak ujar yang dipakai secarasistemik untuk menyelesaikan tujuan-tujuan tertentu (Austin dalam Tarigan, 1990:145).

Salah satu bentuk bahasa yang digunakan manusia untuk berkomunikasi adalah bahasa lisan. Menurut Searle (dalam Rani, 2006:158) komunikasi bahasa bukan sekedar lambang, kata, kalimat melainkan juga berwujud perilaku tindak tutur. Tindak tutur adalah produk atau hasil dari suatu kalimat dalam kondisi tertentu dan merupakan kesatuan terkecil dari komunikasi bahasa yang berwujud pernyataan, pertanyaan, dan perintah. Searle (dalam Rahardi, 2003:70) menyatakan bahwa dalam praktik penggunaan bahasa di masyarakat, terdapat setidaknya tiga macam tindak tutur yang harus dipahami bersama. Ketiga macam tindak tutur di dalam pemakaian bahasa yang sesungguhnya di masyarakat tersebut secara berturut-turut terdiri atas ini: (1) tindak lokusi (locutionary acts), (2) tindak ilokusi (illocutionary acts), dan (3) tindak perlokusi (percolutionary acts).

Pada penelitian ini hanya dibatasi pada tindak tutur ilokusi. Austin (dalam Rani, 2006:161) mengatakan bahwa tindak ilokusi adalah aktivitas bertutur kalimat yang disertai tanggung jawab bagi si penuturnya untuk melakukan suatu tindakan tertentu. Tuturan bisa digunakan oleh siapa saja dan di mana saja, baik situasi formal maupun nonformal, dan baik tempat menuntut ilmu maupun tempat mencari nafkah, seperti pasar.

Pasar merupakan tempat berkumpulnya penjual dan pembeli untuk melakukan interaksi jual beli (https://www.maxmanroe.com/). Pada interaksi jual beli yang dilakukan masyarakat di pasar itu terjadi peristiwa dan tindak tutur. Tindak tutur yang terjadi pada penjual dan pembeli sangat menarik karena mereka menggunakan bahasa yang efektif. Tuturan-tuturan yang terjadi pun tidak selalu panjang, namun tepat sasaran. Objek pasar yang dipilih oleh peneliti yaitu Pasar Tempurejo. Pasar Tempurejo adalah pasar tradisional yang sering dikunjungi oleh masyarakat yang tinggal di Desa Tempurejo dan sekitarnya sehingga tindak tutur yang digunakan beragam. Penjual dan pembeli di Pasar Tempurejo dalam bertutur menggunakan dua bahasa, yaitu bahasa Madura dan bahasa Jawa, tetapi yang lebih dominan bahasa Madura.

Interaksi antara penjual dan pembeli di pasar terikat oleh strategi tutur untuk mencapai sebuah tujuan. Penjual menerapkan strategi tutur agar barang dagangannya laku dan mendapatkan keuntungan atau penjual menciptakan sebuah strategi untuk mempertahankan 
harga yang telah ditentukan. Di sisi lain, pembeli juga menerapkan strategi tutur untuk mendapatkan barang yang diinginkan dengan harga yang murah tapi berkualitas tinggi. Penjual dan pembeli memiliki cara atau strategi bertutur yang menarik agar tuturan yang disampaikan tercapai sesuai target.Tindak tutur yang sering digunakan dalam interaksi jual beli di Pasar Tempurejo yaitu tindak tutur ilokusi dan strategi tawar menawar sehingga rumusan masalah dalam penelitian ini berkaitan dengan tindak tutur ilokusi dan strategi tawar menawar yang digunakan antara penjual dan pembeli di Pasar Tempurejo Kabupaten Jember. Tujuan dari penelitian ini untuk mendeskripsikan tindak tutur ilokusi dan strategi tawar menawar yang digunakan antara penjual dan pembeli di Pasar Tempurejo Kabupaten Jember.

\section{METODE}

Penelitian ini menggunakan metode deskriptif. Metode deskriptif adalah metode yang bertujuan membuat deskripsi, gambaran, lukisan secara sistematis, faktual, dan akurat mengenai data, sifat-sifat serta hubungan fenomena-fenomena yang diteliti (Djajasudarma, 1993:8). Metode deskriptif digunakan untuk memaparkan data yang diperoleh langsung dari objek penelitian yaitu hasil percakapan antara penutur dan mitra tutur dari interaksi jual beli di Pasar Tempurejo, Kecamatan Tempurejo, Kabupaten Jember. Tahap pertama dalam penelitian ini yaitu penyediaan data. Menurut Sudaryanto (1993:131) penyediaan data adalah penyediaan data yang benar-benar data, penyediaan data yang terjamin sepenuhnya akan kesahihannya. Metode yang digunakan dalam tahap penyediaan data adalah metode simak. Peneliti melakukannya dengan cara menyimak tuturan yang terjadi antara penutur dan mitra tutur. Dalam metode simak terdapat beberapa teknik yaitu teknik Simak Bebas Libat Cakap (SBLC), teknik rekam, dan teknik catat. Tahap kedua yaitu analisis data. Metode analisis data yang digunakan adalah metode Padan dan teknik lanjutannya teknik Pilah Unsur Penentu (PUP). Tahap ketiga yaitu penyajian hasil analisis data dengan metode penyajian informal, karena perumusan hasil analisis data menggunakan kata-kata biasa.

\section{HASIL DAN PEMBAHASAN}

Berdasarkan hasil penelitian yang telah dilakukan, akhirnya ditemukan bentuk tindak tutur ilokusi dan strategi tawar-menawar dalam interaksi jual beli di Pasar Tempurejo Kabupaten Jember. Temuan tersebut sebagai berikut. 


\section{Deskripsi Bentuk Tindak Tutur Ilokusi Asertif Menjelaskan}

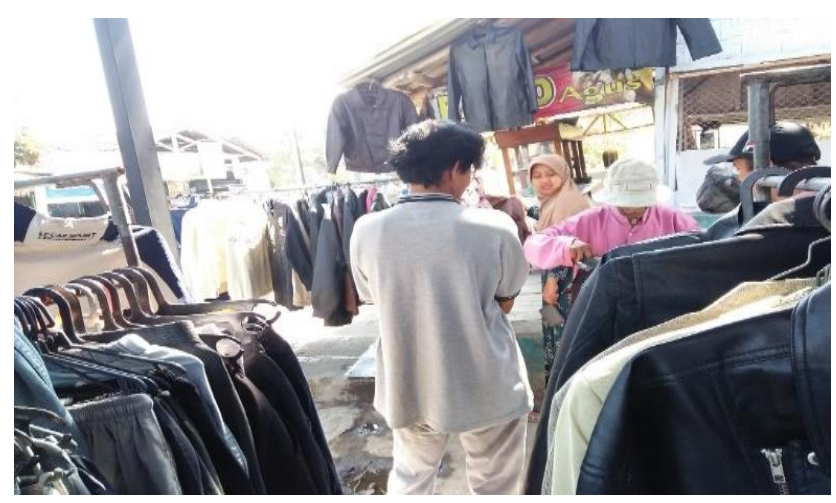

Gambar 1. Penjual Menjelaskan Harga Barang Dagangannya (Foto: Resti Purnama Sari)

Konteks:

Tuturan ini terjadi antara penjual dan pembeli pedagang babebo di pasar. Tuturan ini terjadi ketika penjual menunjukkan celana dari harga yang murah sampai harga yang mahal. Pembeli bertanya kepada penjual karena masih kebingungan dengan celana yang ada di sebelah barat dan timur mengapa harganya berbeda, lalu penjual menjelaskan kepada pembeli mengapa harganya berbeda, karena yang di sebelah timur kualitasnya lebih bagus jika dibandingkan dengan yang di sebelah barat.

Tuturan:

(1) Penjual : Câm-macâm tang bhâreng rèh pa', ruah dupolowan mon riyah pa' polowan

[câm-macâm tạ bârəク rch pa?, ruah dupolowan mon riyah pa? polowan]

'Bermacam-macam barangku ini pak, itu dua puluh ribuan kalau ini empat puluh ribuan'

(Menunjukkan celana yang berada di sebelah barat kepada pembeli)

(2) Pembeli : Ruah, bârâmpa kabbhi bik sè ghellâ'

[ruah, bârâmpa kabbi i bi? se ghəllâ?]

'Itu, berapa semuanya sama yang tadi'

(Menunjuk ke celana yang bagian sebelah barat sambil menunjuk barang yang sudah dia pilih)

Data di atas termasuk tindak tutur ilokusi asertif antara penjual dan pembeli. Tuturan (1) termasuk tindak tutur asertif karena menjelaskan perbedaan harga celana. Penjual menjelaskan kepada pembeli bahwa barang yang dijual itu bermacam-macam harganya, mulai yang kualitas biasa sampai dengan kualitas yang bagus. Harga celana yang di sebelah barat dan timur harganya berbeda karena kualitasnya pun berbeda. Jika celana yang sebelah timur harganya empat puluh ribuan karena kualitasnya lebih bagus dan celananya masih terlihat barang baru bukan bekas ataupun barang lama, sedangkan celana yang sebelah barat harganya dua puluh ribuan karena celananya sudah terlihat barang lama dan warnanya sedikit kusam. Oleh karena itu, harga celana yang di sebelah timur lebih mahal daripada celana yang di 
sebelah barat. Tuturan tersebut maksudnya agar pembeli mudah untuk membeli celana sesuai yang diinginkan dari harga yang dua puluh ribuan sampai empat puluh ribuan. Pada tuturan (1) penjual menyebutkan harga "dupolowan" [dupslowan] maksudnya dua puluh ribuan (Rp 20.00,00-an) dan "pa' polowan" [pa? polowan] maksudnya empat puluh ribuan (Rp 40.000,00-an). Tuturan tersebut merupakan bahasa pasar yaitu informasi harga yang diberikan penjual kepada pembeli dengan tidak menggunakan bahasa baku agar pembeli lebih mengerti dengan tuturan tersebut.

\section{Direktif Merekomendasi Barang}

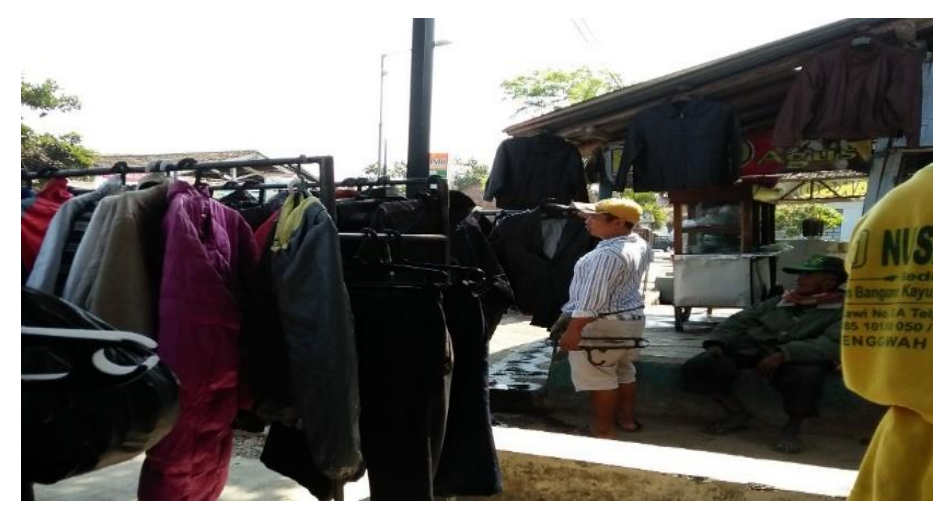

Gambar 2. Penjual Merekomendasi Jaket Kulit kepada Pembeli

(Foto: Resti Purnama Sari)

Konteks:

Tuturan ini terjadi antara penjual dan pembeli baju babebo di pasar. Tuturan terjadi ketika penjual sedang duduk-duduk lalu penjual menghampiri pembeli yang sedang melihatlihat baju, kemudian penjual merekomendasikan jaket kulit kepada pembeli, namun pembeli menolaknya karena sudah memiliki jaket kulit di rumahnya.

Tuturan

(3) Penjual : Riah pa' kolè'

[riyah pa? kole?]

'Ini pak kulit'

(Menunjukkan jaket kulit hitam pada pembeli )

(4) Pembeli : Enjâ', endi' ko' lah èromah

[ənjâ? əndi? ko? lah عromah]

'Tidak, saya sudah punya di rumah'

(Berdiri sambil melihat ke jaket kulit tersebut)

Data tersebut termasuk tindak tutur ilokusi direktif antara penjual dan pembeli di pasar. Tuturan (3) termasuk tindak tutur direktif merekomendasikan jaket kulit. Penjual merekomendasikan jaket kepada pembeli saat pembeli sedang melihat-lihat dagangan penjual tersebut. Jaket yang direkomendasikan oleh penjual yaitu jaket kulit asli namun barang lama tetapi kualitasnya masih bagus. Oleh karena itu, penjual merekomendasikan kepada pembeli untuk membelinya tetapi pembeli menolaknya karena sudah memiliki jaket kulit di rumahnya 
Tindak Tutur Ilokusi dalam Interaksi Jual Beli di Pasar Tempurejo, Jember (Resti Purnama Sari, Akhmad Sofyan, A. Erna Rochiyati S.)

dan tidak ingin menambah jaket kulit lagi. Tuturan tersebut maksudnya agar pembeli membeli jaket kulit tersebut karena jaket kulit tersebut kualitasnya bagus.

\section{Ekspresif Berterima Kasih}

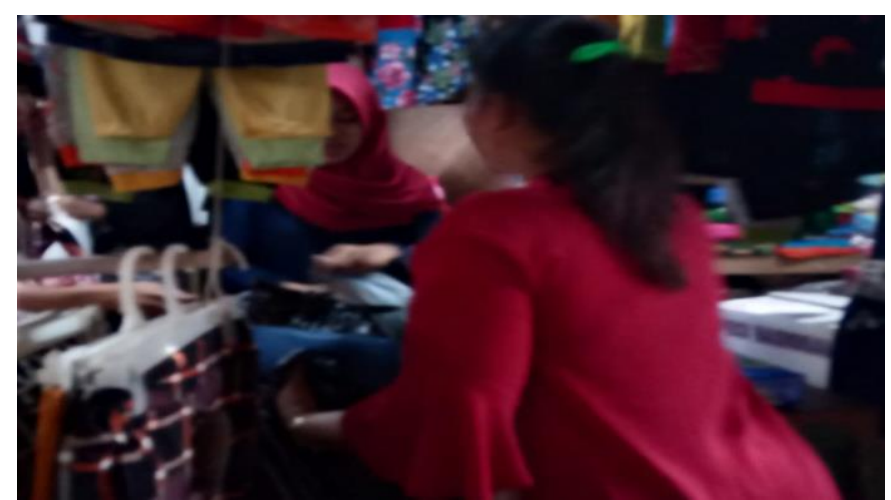

Gambar 3. Penjual Memasukkan Jubah ke Kresek dan Memberikan Kepada Pembeli (Foto: Resti Purnama Sari)

Konteks:

Tuturan ini terjadi antara penjual dan pembeli di toko baju. Tuturan ini terjadi ketika penjual menyetujui tawaran pembeli, kemudian pembeli mengucapkan terima kasih kepada penjual karena telah menyetujui tawarannya.

Tuturan

(5) Penjual : Soso' sâpolo yâh bu', setrika bu' ma' mapan mon èyangguy ta' longset

[səsว? sâpolı yâh bu?, sətrika bu? mapan mon cyanguy ta? lonsət]

'Kembali sepuluh ribu ya buk, disetrika buk agar bagus kalau dipakai tidak kusut'

(Memberikan uang kembalian kepada pembeli sambil menjelaskan kepada pembeli)

(6) Pembeli : Iyâh, dhina ma' tang ana' sèmesot. Iyâhlah keso'on bing, keburuh ko' èdentè' tang ana' èyade'

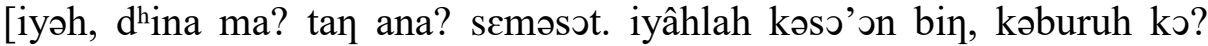
$\varepsilon d ə n t \varepsilon ?$ tan ana? cyadə?]

'Iya, biyar anakku yang nyetrika. Iya sudah terima kasih nak, terburuburu aku ditunggu anakku di depan'

(Mengambil uang kembalian yang diberikan oleh penjual dan memasukkan uangnya ke dompetnya lalu pergi meninggalkan penjual)

Data di atas termasuk tindak tutur ilokusi ekspresif antara penjual dan pembeli di pasar. Tuturan (6) termasuk tindak tutur ekspresif berterimakasih kepada penjual. Pembeli berterima kasih kepada penjual karena penjual menerima tawarannya dengan menurunkan harga jubah yang awalnya seratus enam puluh ribu ( $\mathrm{Rp} 160.000,00)$ kemudian turun menjadi seratus tiga puluh ribu (Rp 130.000,00). Tuturan tersebut menunjukkan rasa senang dan gaya akrab pembeli kepada penjual. Pada tuturan (5) penjual menyebutkan harga "sâpolo" [sâpolo] 
maksudnya sepuluh ribu rupiah (Rp 10.000,00). Tuturan tersebut merupakan bahasa pasar yaitu informasi harga yang diberikan penjual kepada pembeli dengan tidak menggunakan bahasa baku agar pembeli lebih mengerti dengan tuturan tersebut.

\section{Komisif Menawar Barang}

Konteks:

Tuturan ini terjadi antara penjual dan pembeli di toko baju. Tuturan terjadi ketika pembeli menawar kemeja monalisa kepada penjual, namun penjual menolaknya karena pembeli menawar dengan harga yang sangat jauh dari harga yang telah ditentukan penjual.

Tuturan:

(7) Pembeli : Pa' polo lah

[pa? polı lah]

'Empat puluh ribu rupiah sudah'

(Mencoba kemeja sambil menawar kepada penjual)

(8) Penjual : Monalisa jih tak olle mon pa' polo, sèket kala' lah

[monalisa jih ta? ১llə mon pa? polっ, scket kala? lah]

'Monalisa itu tidak boleh kalau empat puluh ribu rupiah, lima puluh ribu rupiah ambil sudah'

(Menggelengkan kepala dan menjelaskan kepada pembeli)

Data di atas termasuk tindak tutur ilokusi komisif antara penjual dan pembeli di pasar. Tuturan (7) termasuk tindak tutur komisif menawar kemeja monalisa. Pembeli menawar kemeja monalisa kepada penjual dengan harga empat puluh ribu rupiah ( $R p$ 40.000,00). Namun, penjual menolaknya karena tawaran dari pembeli sangat jauh dari harga yang telah ditentukan oleh penjual. Akhirnya penjual menetapkan jika harga pasnya kemeja monalisa tersebut lima puluh ribu rupiah $(\mathrm{Rp} 50.000,00)$ kepada pembeli. Tuturan tersebut maksudnya agar penjual menurunkan harga kemeja monalisa tersebut dan pembeli mendapatkan harga yang lebih murah. Pada tuturan (8) penjual menyebutkan "monalisa" yang dimaksudkan ini yaitu kemeja yang terbuat dari kain monalisa. Kain monalisa ini banyak motif dan warnanya seperti bunga-bunga dengan warna yang cerah. Dalam tuturan tersebut penjual sering menyebutkan kata "monalisa", hal tersebut dilakukan agar pembeli lebih tertarik untuk membeli kemeja tersebut.

\section{Deklaratif Menentukan Barang}

Konteks:

Tuturan ini terjadi antara penjual dan pembeli di pasar. Tuturan ini terjadi ketika penjual menawarkan rok yang bermotif pink hitam putih kepada pembeli. Namun, pembeli merasa tidak cocok dan pembeli lebih memilih membeli rok yang berwarna biru tua polos.

Tuturan

(9) Penjual : Ya'a loh rok plisket mapan, cengngo' rah

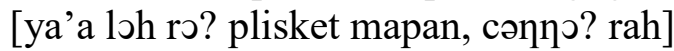
'Ini loh rok plisket bagus, coba lihat ini' 
(Membujuk pembeli sambil memperlihatkan rok yang bercorak pink hitam putih tersebut kepada pembeli)

(10) Pembeli : Ngodâ ghâllu jiyâh, sè ya’a beihlah, dhuli passa bârâmpa?

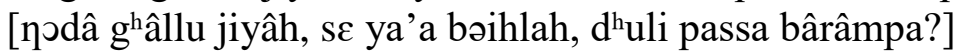

'Terlalu muda itu, yang ini aja sudah, cepat berapa pasnya?'

(Memegang rok yang ditunjukkan oleh penjual kemudian meletakkan lagi di tempatnya)

Data di atas termasuk tindak tutur ilokusi deklaratif antara penjual dan pembeli di pasar. Tuturan (10) termasuk tindak tutur deklaratif menentukan memilih rok. Pembeli menentukan bahwa akan membeli rok yang berwarna biru tua polos kepada penjual karena pembeli lebih cocok dengan rok biru tua polos tersebut daripada rok yang bermotif pink hitam putih. Menurut pembeli, rok yang ditawarkan oleh penjual itu lebih cocok untuk anak muda, tidak cocok untuknya karena pembeli merasa sudah tua dan tidak muda lagi. Oleh karena itu, pembeli lebih memilih untuk membeli rok yang berwarna biru tua polos. Tuturan tersebut dimaksudkan agar penjual mengerti bahwa pembeli memilih untuk membeli rok yang berwarna biru tua polos. Pada tuturan (9) penjual menyebutkan plisket, maksudnya plisket ini adalah rok yang dibuat dengan kain plisket yang bertekstur berlipat-lipat. Kata plisket berasal dari kata "pleated skirt" tetapi agar lebih mudah pengucapannya, disebutnya dengan kata plisket. Kata plisket sering digunakan dalam interaksi jual beli baju di pasar. Hal tersebut dilakukan penjual untuk menarik perhatian pembeli agar membeli rok plisket tersebut.

\section{Strategi Tuturan Tawar-menawar Strategi Menawarkan dengan Menyapa}

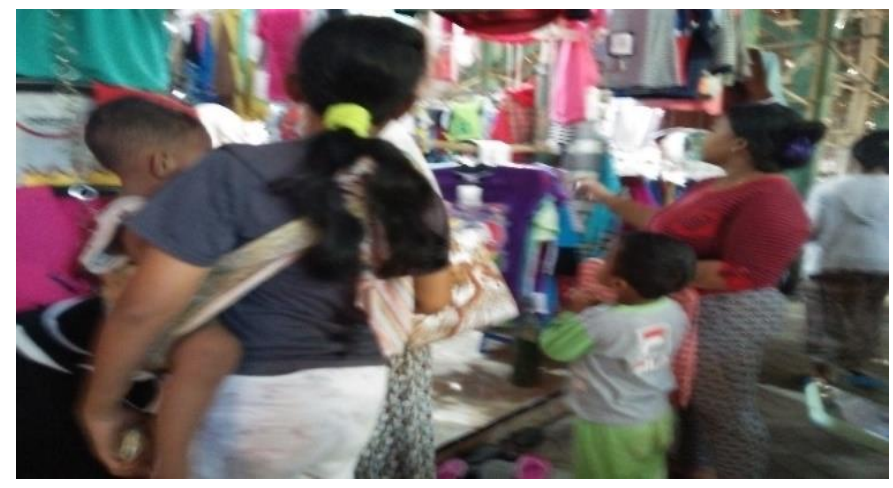

Gambar 5. Pembeli Menghampiri Penjual

(Foto: Resti Purnama Sari)

Konteks:

Tuturan ini terjadi antara penjual dan pembeli di gerai lesehan pasar. Tuturan ini terjadi ketika seorang wanita lewat di depan gerai penjual kemudian penjual menyapa pembeli dengan menawarkan daster, lalu wanita tersebut menghampiri penjual dan menjelaskan kepada penjual bahwa dia mencari baju untuk anaknya. 
Tuturan

(11) Penjual : Nyarèh apah bing, ya daster pan mapan bing, mèlè dhulilah [ñarch apah bin, ya dastər pan mapan bin, mele d ${ }^{\text {h }}$ lilah] 'Mencari apa Nak, ini daster bagus-bagus Nak, milih sudah'

(Menyapa wanita yang lewat depan gerai dagangannya dengan nada merayu)

(12) Pembeli : Nyarèh klambih ghâbây ya'a loh mbo' [ñarch klambih ghâbây ya'a loh mbo?]

'Mencari baju untuk ini loh buk'

(Menghampiri penjual sambil menggandeng anak perempuannya)

Data di atas termasuk strategi tawar-menawar dalam interaksi jual beli di pasar. Tuturan (11) termasuk strategi menawarkan yang dilakukan oleh penjual dengan menyapa pembeli. Ketika ada seorang wanita yang melewati gerai penjual baju, penjual segera menyapa wanita itu dengan menawarkan daster. Penjual menawarkan daster kepada wanita tersebut dan menyuruhnya untuk memilih-milih siapa tahu ada yang cocok. Akhirnya wanita tersebut menghampiri penjual dan menjelaskan bahwa dia ingin mencari baju untuk anak perempuannya. Strategi menyapa yang dilakukan oleh penjual agar pembeli tertarik untuk membeli dagangannya. Namun, strategi menyapa pembeli ini tidak berhasil menarik pembeli untuk membeli barang dagangan penjual.

\section{Strategi Menawar dengan Mengancam Pergi}

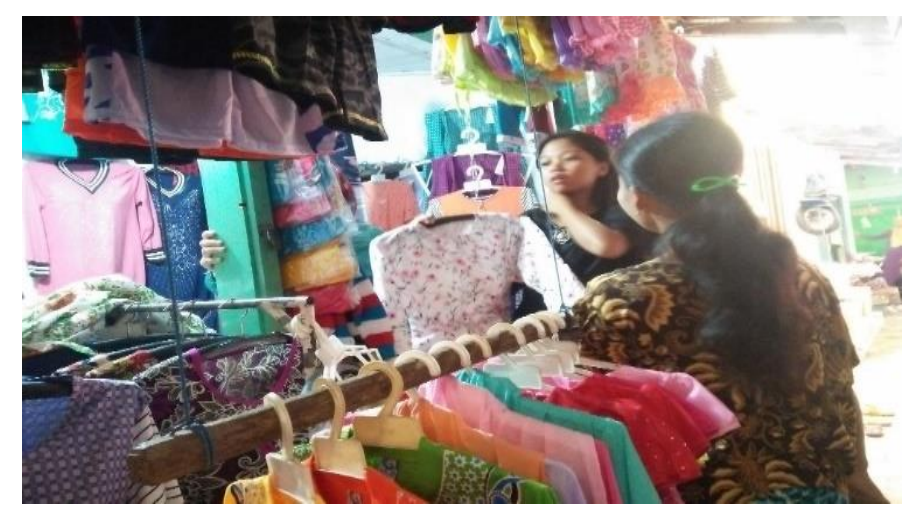

Gambar 6. Pembeli Sedang Menawar Baju Kepada Penjual (Foto: Resti Purnama Sari)

Konteks:

Tuturan ini terjadi antara penjual dan pembeli di pasar. Tuturan ini terjadi ketika pembeli berulang kali menawar baju atasan kepada penjual, namun penjual tetap tidak menurunkan harga. Oleh karena itu, pembeli menawar dengan mengancam pergi jika penjual tetap tidak menurunkan harga. Akhirnya penjual menyetujui tawaran dari pembeli.

Tuturan

(13) Pembeli : Sèket limo mba' niki wis tak tambahi lima ngèwu [scket lim $\mathrm{mba}$ ? niki wIs ta? tambahi lima $\eta \varepsilon w u$ ] 'Lima puluh ribu rupiah mbak ini sudah saya tambah lima ribu rupiah' 
(Memegang baju dan meletakkan di atas baju yg lain)

(14) Penjual : Gak entok lèk semunu ndu', kulak.ane ae gak entok sèket limo

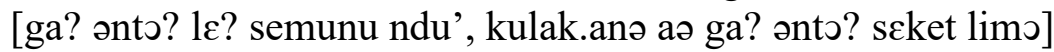

'Tidak boleh kalau segitu dek, belinya saja tidak boleh lima puluh lima ribu rupiah'

(Berdiri sambil menggelengkan kepala kepada pembeli)

(15)Pembeli : Sewidha' pun niku passe nggeh

[sewidha? pun niku passə ๆgəh]

'Enam puluh ribu rupiah itu pasnya ya'

(Berjalan beranjak pergi meninggalkan pedagang)

(16)Penjual : Iyo wis ndu' ndang ndang rene

[iyo wIs ndu? ndaך ndą rənə]

'Iya sudah dek cepat cepat sini'

(Memanggil sambil melambaikan tangan agar pembeli kembali lagi)

Data di atas termasuk strategi tawar-menawar dalam interaksi jual beli di pasar. Tuturan (15) termasuk strategi menawar dengan gaya mengancam pergi yang dilakukan pembeli kepada penjual. Pembeli menawar baju atasan kepada penjual namun, penjual tidak menurunkan harganya walaupun pembeli sudah berulang kali menawar kepada penjual. Penjual akan menurunkan harga jika pembeli menambahkan harga yang sudah ditawar sebelumnya karena harga baju atasan tersebut harganya tidak bisa kurang. Oleh karena itu penjual menolak tawaran dari pembeli. Namun, pembeli tidak pantang menyerah tetap menawar harga baju atasan tersebut dengan menambah sedikit harga dan mengancam pergi jika tawarannya ditolak. Pembeli sebenarnya tidak sepenuhnya ingin pergi meninggalkan penjual, hal tersebut dilakukan pembeli agar penjual menurunkan harga baju atasan tersebut dengan harga enam puluh ribu rupiah ( $\mathrm{Rp} \mathrm{60.000,00).} \mathrm{Pembeli} \mathrm{menggunakan} \mathrm{strategi}$ menawar dengan gaya ancaman karena penjual tetap tidak mau menurunkan harga meskipun pembeli sudah berulang kali menawar. Oleh karena itu, strategi pembeli menawar dengan gaya ancaman merupakan strategi terakhir agar penjual mau menurunkan harga. Akhirnya penjual menyetujui tawaran dari pembeli. Startegi dengan gaya ancaman yang dilakukan oleh pembeli berhasil membuat penjual menyetujui tawarannya.

\section{Strategi Menyetujui Tawaran setelah Ditawar}

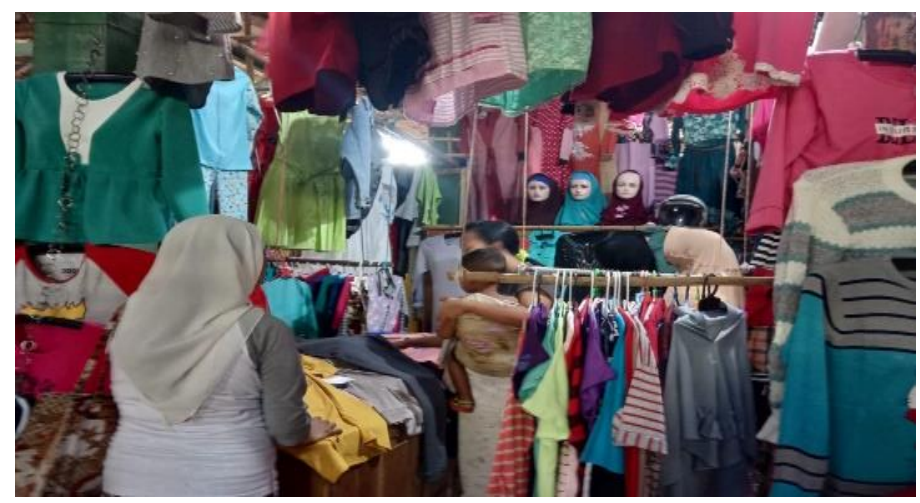

Gambar 7. Penjual Menyetujui Tawaran Pembeli (Foto: Resti Purnama Sari) 
Konteks:

Tuturan ini terjadi antara penjual dan pembeli di toko baju. Tuturan ini terjadi ketika pembeli menawar harga baju kepada penjual karena harga yang diberikan oleh penjual terlalu mahal. Penjual menyetujui tawaran yang dilakukan oleh pembeli karena penjual ingin dagangannya laku.

Tuturan

(17)Penjual : Sanga' lèma' lah yu

[sana' lema' lah yu]

'Sembilan puluh lima ribu rupiah sudah yu'

(Meyakinkan pembeli sambil tersenyum)

(18)Pembeli : Korangilah ma' pas sedekyeh, bâlumpolo lah. njâ' rang larang yu. Pas lah bâlumpoloh yâh.

[kəranilah ma? pas sədəkyəh, bâlumpəlo lah. njâ? rạ larą yu. Pas lah bâlumpolı yâh]

'Kurangilah kok segitu, delapan puluh ribu rupiah sudah. Jangan mahal-mahal mba'. Pas delapan puluh ribu rupiah ya'

(Menggendong anaknya yang masih kecil sambil merayu penjual)

(19)Penjual : Iyâhlah lè'. Tambe kaos pollè dhuli mèleh, pan mapan kaossah ghi' buruh dhâteng

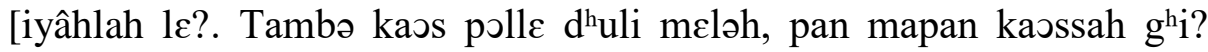
buruh dhâtəๆ]

'Iya sudah dek. Tambah kaos lagi sana milih, bagus-bagus kaosnya baru datang'

(Menyuruh pembeli membeli kaos yang ada dibagian depan)

Data tersebut termasuk strategi tawar-menawar dalam interaksi jual beli di pasar. Tuturan (19) termasuk strategi menyetujui tawaran setelah ditawar yang dilakukan oleh penjual kepada pembeli. Penjual menjelaskan bahwa harga baju yang dimaksudkan oleh pembeli tersebut sembilan puluh lima ribu rupiah (Rp 95.000,00). Namun, pembeli meminta kepada penjual untuk menurunkan harganya karena mahal. Pembeli menawar celana jeans tersebut dengan harga delapan puluh ribu rupiah (Rp 80.000,00) kepada penjual, kemudian penjual menyetujui tawaran pembeli tersebut karena penjual tidak ingin kehilangan pembeli. Meskipun penjual hanya mendapatkan keuntungan sedikit dari hasil menjual celana jeans tersebut. Hal tersebut dilakukan oleh penjual agar dagangannya laku terjual. Strategi menawar yang dilakukan oleh pembeli berhasil membuat penjual langsung menyetujui tawarannya dan strategi penjual menyetujui tawaran setelah ditawar berhasil membuat dagangannya cepat laku terjual.

\section{Strategi Penjual Menolak Tawaran dengan Dalih Merugi}

Konteks:

Tuturan ini terjadi antara penjual dan pembeli di gerai lesehan di pasar. Tuturan ini terjadi ketika pembeli ingin membeli celana pendek lalu menawarnya namun penjual menolak tawaran dari pembeli karena penjual akan rugi. 
Tindak Tutur Ilokusi dalam Interaksi Jual Beli di Pasar Tempurejo, Jember (Resti Purnama Sari, Akhmad Sofyan, A. Erna Rochiyati S.)

Tuturan

(20) Pembeli: Bârâmpa mon lebber riah?

[bârâmpa mon ləbbər riah?]

'Berapa kalau celana pendek ini?

(Memegang celana pendek dan meunjukkan kepada penjual)

(21) Penjual: Pètto bellâs

[petto bellâs]

'Tujuh belas ribu rupiah'

(Duduk sambil melipat barang dagangannya)

(22)Pembeli : Dupolo duwâ'

[dupolı duwâ?]

'Dua puluh ribu dapat dua'

(Memilih-milih celana pendek yang di depannya)

(23)Penjual : Ta' ollè, tello polo lah, jih lah korting duwibuh, njâ' nyak-benya' kortingah tekor.

[ta? ১lle, təllə pələh lah, jih lah kərtin duwibuh, njə? ñak-bəña? kərtinah təkər]

'Tidak boleh, tiga puluh ribu sudah, itu sudah korting dua ribu rupiah, jangan banyak-banyak kortingnya rugi'

(Meyakinkan pembeli dengan nada lembut jika harga itu sudah murah)

Data tersebut termasuk strategi tawar-menawar dalam interaksi jual beli di pasar. Tuturan (23) termasuk strategi penjual menolak tawaran dengan dalih merugi yang dilakukan oleh penjual kepada pembeli. Pembeli bertanya harga celana pendek kepada penjual, kemudian penjual memberitahukan bahwa harga celana pendek tersebut tujuh belas ribu rupiah (Rp 17.000,00). Pembeli ingin membeli dua buah celana pendek, hal tersebut dilakukan pembeli untuk mendapatkan harga yang lebih murah dibandingkan dengan membeli satu buah celana dalam. Oleh karena itu, pembeli menawar harga dua buah celana pendek tersebut kepada penjual dengan harga dua puluh ribu rupiah ( $R p$ 20.00,00). Namun, penjual menolak tawaran dari pembeli karena harga yang ditawar oleh pembeli itu terlalu murah. Penjual menawarkan jika harga dua buah celana pendek tersebut dengan harga tiga puluh ribu rupiah $(\mathrm{Rp} 30.000,00)$ karena harga tersebut sudah dikorting oleh penjual tidak bisa turun lagi, jika harga turun lagi penjual akan rugi tidak mendapatkan keuntungan sama sekali. Strategi pembeli menawar celana pendek tersebut tidak berhasil membuat penjual menyetujui tawarannya dan strategi penjual menolak tawaran dengan dalih merugi tidak berhasil membuat pembeli tertarik untuk membeli dagangannya.

\section{SIMPULAN}

Dalam penelitian ini bentuk tindak tutur ilokusi yang dilakukan dalam interaksi jual beli di Pasar Tempurejo meliputi: tuturan asertif yaitu tuturan menjelaskan harga barang, memberitahukan harga barang, mengeluhkan harga barang, dan menyarankan barang. Tuturan direktif meliputi tuturan memerintah mencari barang, dan merekomendasi barang. Tuturan ekspresif meliputi tuturan mengucapkan terima kasih, memuji pembeli, mengkritik kualitas barang, dan memastikan penjual. Tuturan komisif meliputi tuturan menawar barang. Tuturan 
deklaratif meliputi tuturan menentukan barang. Tindak tutur ilokusi yang sering digunakan dalam interaksi jual beli di Pasar Tempurejo yaitu tuturan asertif dan tuturan ekspresif.

Strategi tawar-menawar yang dilakukan oleh penjual dan pembeli meliputi: strategi menawarkan dengan menyapa pembeli, strategi menawarkan dengan memuji pembeli, strategi menawarkan dengan menurunkan harga, strategi menyetujui tawaran karena langganan, strategi menyetujui tawaran setelah ditawar, strategi menyetujui tawaran dengan syarat memborong dagangan, strategi menolak tawaran dengan dalih harga pas dan strategi menolak tawaran dengan dalih merugi. Strategi menawar dengan menurunkan kualitas barang dagangan penjual, strategi menawar karena harga terlalu mahal, dan menawar dengan gaya ancaman. Strategi tawar-menawar yang sering digunakan dalam interaksi jual beli di Pasar Tempurejo yaitu strategi menawarkan. Strategi tawar-menawar yang dilakukan oleh penjual dan pembeli dalam interaksi jual beli di Pasar Tempurejo ada yang berhasil dan ada yang tidak berhasil.

\section{DAFTAR PUSTAKA}

Djajasudarma, T.F. 1993. Metode Linguistik (Ancangan Metode Penelitian dan Kajian). Bandung: Angkasa.

https://www.maxmanroe.com/vid/bisnis/pengertian-pasar.html. 2019. "Pengertian Pasar dalam Ilmu Ekonomi, Ciri-ciri- Fungsi, dan Jenis-jenis Pasar”. (Diakses 25 April 2019).

Keraf, G.S. 2001. Tata Bahasa Indonesia. Ende: Nusa Indah.

Kridalaksana, H. 1993. Kamus Linguistik. Jakarta: PT Gramedia Pustaka Utama.

Rahardi, K. 2003. Berkenalan dengan Ilmu Bahasa Pragmatik. Malang: Dioma.

Rani, A. 2006. Analisis Wacana: Sebuah Kajian Bahasa dalam Pemakaian. Malang: Bayumedia.

Sudaryanto. 1993. Metode dan Aneka Teknik Analisis Bahasa. Yogyakarta: Duta Wacana University Press.

Tarigan, H.G. 1990. Pengajaran Pragmatik. Bandung: Angkasa. 